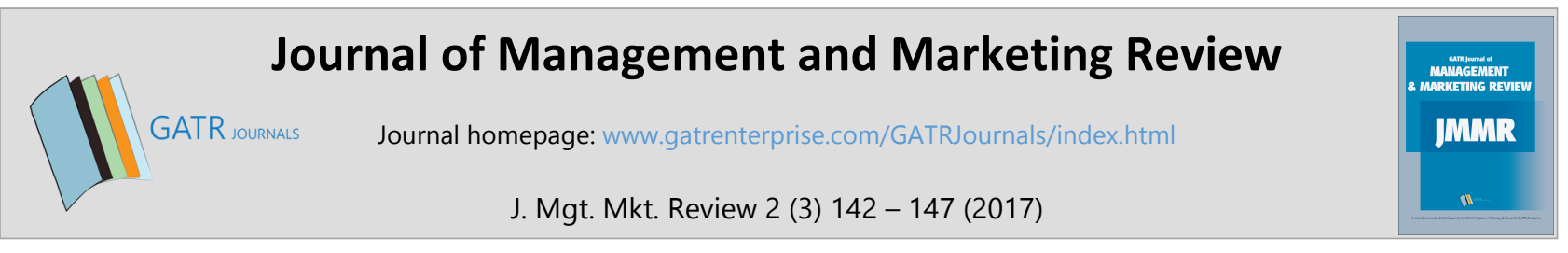

\title{
Inter-Governmental Relation in City Bus Public Transportation Service in Surakarta in Indonesia
}

\author{
Kristina Setyowati ${ }^{1 *}$ and Tya Astriyani ${ }^{2}$ \\ ${ }^{1,2}$ Public Administration Department of Social and Political Sciences Faculty, Sebelas Maret University, Indonesia.
}

\begin{abstract}
Objective - The objective of research was to determine the intergovernmental relation in public transport services. It also aims to identify the inter-governmental Relation in the service of Batik Solo Trans viewed from the cooperation type, the cooperation process and examined using three aspects: sharing of benefits, sharing of burden and sharing of experience.

Methodology/Technique - The research method was qualitative descriptive one with interview and documentation as the technique of collecting data. The sampling technique used was purposive sampling on. Data validation was carried out using method triangulation and data analysis using an interactive data analysis.

Findings - Considering the result of research, it could be found that the type of inter- Governmental Relation in BST Service was the collective agreement without certain pact document. The cooperation process was done in coordinative manner. The cooperation showed the existence of benefit sharing between the areas involved. Besides, cooperation was also used as the media of sharing experiences, but it didn't show the distribution of responsibility.

Novelty - The study recommends that there should be an agreement document specifically governing the intergovernmental cooperation in BST service, enabling the sharing of burdens so that the cooperation can be proposed with the distribution of responsibility between the areas involved.
\end{abstract}

Type of Paper: Empirical

Keywords: Inter-Regional Relation; Cooperation; Public Transport Service, City Bus.

JEL Classification: O18, O31.

\section{Introduction}

Surakarta City is also surrounded by some hinterland areas: Karanganyar, Sukoharjo and Boyolali Regencies. Such the strategic position makes Surakarta the hub of activity node or business center important to the surrounding areas.

The growth of Surakarta city's population increases over years. The population-dense condition of area has implication to the people's settlement pattern spreading to hinterland areas. Such the settlement pattern enables the cross-border population mobility from hinterland to the downtown of Surakarta and vice versa.

\footnotetext{
* Paper Info: Received: January 10, 2017

Accepted: July 18, 2017

* Corresponding author:

E-mail: krist_uns@yahoo.co.id

Affiliation: Social and Political Sciences Faculty, Sebelas Maret University, Indonesia.
} 
In some big cities, public transportation such as city bus in urban areas is an optional model to deal with a variety of traffic problems including reducing the traffic jam, increasing distance reaching, and increasing mobility level (Ismail et al., 2012; Jayaraman et al., 2011; Ponnaluri, 2011).

Government plays an important part in the process of planning and implementing the public transportation policy. Many policies affecting transportation problems should be synchronized, thereby realizing the better one, for example, a program to encourage the use of mass transportation and to reduce private (personal) vehicles (Peñalosa, 2005). Meanwhile, Ponrahono et al. (2015) stated that: "there is a gap of service area and a spatial service imbalance between one region and another, so that a policy in public transportation service is required in order to improve the accessibility and mobility of people in hinterland area to the downtown".

As the form of public service in transportation sector, Surakarta City government released Batik Solo Trans (BST) program. The operation coverage of BST service is not only across Surakarta City but also cross-border, that is, the intersection between hinterland areas: Palur (Karanganyar Regency), Kartasura (Sukoharjo Regency), and Adi Sumarmo Airport (Boyolali Regency).

The cooperation in BST service established by Surakarta city government and its surrounding areas is the form of public service in transportation sector. Recalling the importance of intergovernmental cooperation, this research aims to find out the process and aspects of intergovernmental cooperation in Batik Solo Trans (BST) service.

This cooperation is established for the sake of going forward and solving the problem together, but the effectiveness of cooperation is still low because there has been no intergovernmental commitment and no synchronization with local planning. Some studies have been conducted on cooperation: 1) Prastiti and Wijaya (2012), Marsiadi (2014), and Harsanto et al. (2015) finding, among others: the handshake agreement and fee for service contract and mutual funding and governance.

\subsection{Intergovernmental Cooperation}

Intergovernmental cooperation is a framework of job relation into which two or more areas enter, obviously at equal and balanced level to achieve the mutual objective, to improve the people's welfare (Pamudji, 1985); (Andani \& Maryati, 2013); (Philimore, 2013) defines intergovernmental cooperation as follows: "We can define intergovernmental relations (IGR) as the processes and institutions through which governments within a political system interact".

Patterson in Warsono (2009) (Kwon \& Feiock, 2010): defines intergovernmental cooperation as arrangement two or more governments for accomplishing common goals, providing a service or solving a mutual problem". Meanwhile, regarding the concept and theory of intergovernmental relation defined by: Suryokusumo (2008), Phillimore (2013), Cugleşan (2013), Intergovernmental Relation (IGR) is important to enable its involvement in cross-border cooperation.

The cooperation process developed by one local government and another can be done in some stages. Zaini (2013) suggests that intergovernmental cooperation process is generally conducted in the following stages:

- It is preceded with mutual agreement/decision to enter into cooperation agreement/contract;

- The mutual agreement/decision is followed up with feasibility study and then cooperation agreement/ contract;

- Local leader with the legislative mandate is responsible to the public for its successful/failed cooperation;

Meanwhile, regarding the aspect of cooperation, Yudhoyono in PLOD and APEKSI (2006) states that intergovernmental relation will be beneficial to the areas involved because of some aspects conducted in cooperation. They are: 
- Sharing of benefits. The cooperation is the means of sharing benefit between parties. The management of local potency or the provision of public service collectively will yield mutual benefit.

- Sharing of burdens. Through cooperating, the parties can share responsibility, for example, in the term of development funding, particularly in the development that is inefficient when conducted independently.

- Sharing of experiences. Cooperation is conducted as a means of sharing experiences between the involved parties. Through cooperating, the local areas can share information on experience with each other. The local area's experience with policy implementation will be the reference for other area to learn the inhibiting and supporting factor for the successful policy in an area.

\subsection{City Bus Public Transportation Service}

The development of reliable urban public transportation as the public service focuses on the safe, cheap and comfortable aspects and maximizing the accessibility to the public. It also includes the development of integrated public transportation. Still related to the development of public transportation as the public service in transportation sector, according to Peñalosa (2005), to improve the public transportation sector, particularly in the term of service quantity and quality, is a must.

In article 7 (1) of the Republic of Indonesia's Law Number 22 of 2009 about Traffic and Road Transportation, it is mentioned that:

"The organization of road traffic and transportation in the activity of direct service to the society is conducted by government, local government, legal entity, and/or society". It means that the provider of road transportation/public transportation service is the government/local government's responsibility. The availability of comprehensive public transportation will highly affect a city's mobility.

Setyowati (2015) says:

"that the importance of urban public transportation in catering to urban transportation and facilitating the society in doing their activity in all different locations in all urban areas. The existence of urban public transportation is very desirable particularly to those not having private transportation vehicle or not capable of driving their vehicle".

It is confirmed by Nugroho and Risdianto (2007): "stating that public transportation service should be adequate".

Recently, there are two types of city bus public transportation in Surakarta: DAMRI and BST (Batik Solo Trans) buses. DAMRI city bus belongs to government, while BST belongs to the partnership between the government and the private affiliated with PT. Bengawan Solo Transport. BST is a type of urban transportation vehicle using Bus Rapid Transit, according to Thomas (2001) in Adewumi and Allopi (2014), is defined as "Bus Rapid Transit can simply be defined as a rapid mode of transportation that can coalesce the quality of rail transit and flexibility of a bus".

\section{Method}

This study employed qualitative method; the techniques of collecting data used were in-depth interview and documentation. Data source was determined using purposive sampling technique. The aspects studied included: Sharing of benefits, sharing of burdens, and Sharing of experiences. Data validation was carried out using method triangulation, and data analysis using an interactive analysis.

\section{Result}

Batik Solo Trans (BST) city bus transportation service is released by Surakarta city government has service coverage or route not only across Surakarta City but also reaches the hinterland areas such as Palur (Karanganyar), Kartasura (Sukoharjo) and Airport (Boyolali). Before BST program is implemented, Surakarta 
City government has established cooperation with local government of the area crossed. Therefore, result of this research can be described as follows:

- The cooperation has formed in the inter-governmental relations, particularly in BST service

- Some of the aspects came with the form of the cooperation in the term of the inter-governmental relations of BST service

\section{Discussion}

From the result mentioned above, it will need more explanation for analyzing it. This part of the paper is the discussion of the research, based on the result. There are two parts of the discussion based on the result.

\subsection{Cooperation Form}

Inter-governmental relation in BST service is a mutual agreement between Dishubkominfo (Information Communication Transportation Office) of Surakarta City as the one having BST program with Dishubkominfo of Karanganyar Regency, Dishubkominfo of Sukoharjo Regency, and Dishubkominfo of Boyolali Regency as those whose areas crossed by BST. Such the cooperation does not have special agreement document but based on intergovernmental cooperation agreement throughout Subosukawonosraten (Surakarta, Boyolali, Sukoharjo, Karanganyar, Wonogiri, Sragen, Klaten) in transportation (Road Transportation Traffic) sector. MoU Subosukawonosraten in transportation (Road Transportation Traffic) sector is still general in nature in the form of agreement to manage transportation collectively.

\subsection{Aspects of cooperation}

Intergovernmental cooperation will benefit much the areas involved because there are some points done in cooperation:

\subsubsection{Sharing of Benefits}

- The fulfilment of intergovernmental mobility

The coverage of BST service crossing the four areas: Surakarta, Palur (Karanganyar), Kartasura (Sukoharjo) and Bandara (Boyolali) can fulfil the society's need for inter-regional mobility. The activity of people in Surakarta and surrounding regency not only is limited to individual areas but also the areas' traffic, so that through BST cooperation attempts to accommodate the cross-border community mobility.

- The attempt of dealing with traffic jam and density

The flow of vehicles crossing Surakarta City derives not only from Surakarta but also from surrounding area's community. Therefore, it is well-established that it is one cause of traffic jam and density in Surakarta City. Therefore, BST track through hinterland area is expected to reduce the flow of personal vehicles used by the people of Surakarta City and surrounding area in their mobility.

\subsubsection{Sharing of Burdens}

Other areas do not allocate or have not allocated budget to infrastructure development and maintenance in their local budget, so that other areas only support and give placement license. Before the damage occurs, the infrastructure (bus stop/shelter) of BST for corridor 1 existing in other areas was firstly constructed by Perum Damri as the operator. But after damage, that both in and out of Surakarta City becomes the responsibility of Surakarta City, in this case Dishubkominfo of Surakarta City. 


\subsubsection{Sharing of Experiences}

- Some information is shared; Dishubkominfo of Surakarta City as the owner of BST program, explained the direction of BST corridor/route, in addition to the importance of connectivity or continuity between areas using BST transportation.

- Some information is received as the lesson to the areas involved. There is information received directly by other areas as the form of learning about how to apply bus rapid transit-based transportation such as BST in the future.

From the discussion above, it can be inferred that the form of intergovernmental cooperation in the form of BST service belongs to Handshake Agreement. The characteristic of such the cooperation is mutual agreement without special agreement document governing about BST. Moreover, intergovernmental cooperation in BST service can be seen from the aspects of Sharing benefits including the fulfilment of intergovernmental mobility, the attempt of dealing with traffic jam and density, and increasing local income from the retribution imposed to BST. Viewed from Sharing of burdens aspect, there has been no responsibility distribution related to the funding of BST infrastructure existing in other area. Meanwhile, viewed from Sharing of Experiences, the cooperation is used as the means of sharing experiences and information between the areas involved.

From the conclusion above, the recommendation given is that there should be an agreement document specifically governing the intergovernmental cooperation in BST service, enabling the sharing of burdens so that the cooperation can be proposed with the distribution of responsibility between the areas involved.

\section{References}

Adewumi, E. O., \& Allopi, D. (2014). An Appropriate Bus Rapid Transit System, International Journal of Science and Technology, 3(4).

Andani, I. G. A., \& Maryati, S. (2013). Kriteria Keberhasilan Kerjasama Antar Daerah Dalam Penyediaan Pasokan Air Baku Untuk Perusahaan Daerah Air Minum (PDAM) [Criteria for Successful Inter-Regional Cooperation in Provision of Raw Water Supply for Regional Water Company (PDAM)]. Jurnal Perencanaan Wilayah dan Kota B SAPPK V2N3.

Cugleşan, N. (2013). Regional Decentralisation in Romania and ItsImpact On Cross-border Cooperation, Euroregional Studies Oradea-Debrecen, Babeş-Bolyai University, Cluj-Napoca.

Harsanto, B. T., Rosyadi, S., \& Simin, S. (2015). Format Kelembagaan Kerjasama Antar Daerah untuk Pembangunan Ekonomi Kawasan Berkelanjutan [Institutional Format of Inter-Regional Cooperation for Sustainable Economic Development of the Region]. MIMBAR, Jurnal Sosial dan Pembangunan, 31(1), 211-220.

Ismail, R., Hafezi, M. H., Nor, R. M., \& Ambak, K. (2012). Passengers preference and satisfaction of public transport in Malaysia. Australian Journal of Basic and Applied Sciences, 6(8), 410-416.

Indonesia, P. R. (2009). Undang-undang Republik Indonesia nomor 22 tahun 2009 tentang lalu lintas dan angkutan jalan [Law of the Republic of Indonesia number 22 of 2009 on traffic and road transport]. Eko Jaya.

Jayaraman, K., Suan, J. C. S., \& Lin, S. K. (2011). Robust models for the utilization of public bus transport services in Malaysia. African Journal of Business Management, 5(26), 10586-10600.

Kwon, S. W., \& Feiock, R. C. (2010). Overcoming the barriers to cooperation: Intergovernmental service agreements. Public Administration Review, 70(6), 876-884.

Masriadi. (2014). Intergovernmental Cooperation in provisioning Educational Goods and Service (Study on Intergovernmental on Providence Free Education in South Sulawesi), IOSR Journal Of Humanities And Social Science (IOSR-JHSS), 19(4), 32-39

Nugroho, H. and Risdianto, O. 2007. Model Rute Angkutan Umum Penumpang Dengan Aplikasi Sistem Informasi Geografis (SIG) (studi kasus Kota Semarang ). Jurnal Tata Loka , 9(4).

Pamudji, S. (1985). Kerjasama antar daerah dalam rangka pembinaan wilayah: suatu tinjauan dari segi administrasi negara [Inter-regional co-operation in the framework of regional development: a review in terms of state administration]. Bina Aksara.

Peñalosa, E. (2005). The Role of Transport in Urban Development Policy-revised July 2005. Sustainable Transport: A Sourcebook for Policy-makers in Developing Cities Module 1a. 
Phillimore, J. (2013). Understanding intergovernmental relations: Key features and trends. Australian Journal of Public Administration, 72(3), 228-238.

Ponnaluri, R. V. (2011). Sustainable Bus Rapid Transit initiatives in India: The role of decisive leadership and strong institutions. Transport Policy, 18(1), 269-275. http://doi.org/10.1016/j.tranpol.2010.08.010

Ponrahono, Z., Bachok, S., Osman, M. M., Ibrahim, M., Abdullah, M. F., \& Abdullah, A. (2015). Assessing the urban and rural stage bus services disparities in peninsula Malaysia. PLANNING MALAYSIA JOURNAL, 13(5), 65-84.

PLOD \& APEKSI. (2006). Model Kerjasama antar Daerah, Laporan Akhir. Tidak Dipublikasikan.

Setyowati, K. (2015). Kemitraan Dalam Manajemen Pelayanan Transportasi Publik (Studi Kasus Tentang Pelayanan Angkutan Umum Bus Kota Di Surakarta) [Partnership in Public Transportation Service Management (Case Study About Public Transport Bus Service In Surakarta)], Disertasi, Malang: FIA- Universitas Brawijaya.

Suryokusumo, R. F. A. (2008). Pelayanan Publik dan Pengelolaan Infrastruktur Perkotaan [Public Service and Urban Infrastructure Management]. Yogyakarta: Penerbit Sinergi Publishing.

Warsono, H. (2009). Regionalisasi Dan ManajemenKerjasama Antar Daerah (Studi Kasus Dinamika Kerjasama Antar DaerahYang Berdekatan di Jawa Tengah) [Regionalization and Management of Inter-Regional Cooperation (Case Study of Dynamics of Inter-Regional Cooperation of Nearness in Central Java)], Tesis. Dipublikasikan.

www.solopos.tv/2015/02/21-halte-bst-koridor-iii-akan-dibangun12932. 2015. "21 halte BST koridor III akan dibangun", Solopos, diakses pada 18 September 2015.

http:/www.timlo.net/baca/54058/dilalui-bst-daerahpersinggungan-tidak-masalah/. 2012. "Dilalui BST, Daerah Persinggungan Tidak Masalah", Timlo.net, diakses pada 18 September 2015.

Zainal Abidin, N. Z., \& Singaravelloo, K. (2015). Decentralization and Local Autonomy in South Korea: Lessons for Malaysia. Global Journal of Business and Social Science Review, 3(1) 82-87 